Williams, R. E. O. (1952). J. gen. Microbiol. 7, 89-97

\title{
Investigations into a Method for Counting the Total Number of Bacteria in a Suspension
}

\author{
By R. E. O. WILLIAMS \\ Streptococcal Reference Laboratory, Public Health Laboratory Service, \\ Colindale, London, N.W. 9
}

\begin{abstract}
SLMMARY: Counts were made of the total number of bacteria in cultures by a method that comprised suspension of the cells in molten agar, and the casting of this agar into a thin film in a haemocytometer chamber, followed by removal of the film from the chamber and drying in air. Counting of the bacteria was carried out with the use of a phase-contrast microscope. Statistical analysis of the counts indicated that the principal sources of variation lay in the differences between the numbers of organisms counted in successive microscope fields, between the total numbers in different traverses of the film, and between the primary agar dilutions of the culture.
\end{abstract}

In many experiments where a count of the total number of bacteria in a suspension is required, it would be an advantage if the actual counting could be postponed until the rest of the experiment had been concluded. This is the case, for example, when the suspension has to be used immediately for the absorption of serum or inoculation into animals. The most precise method of making total counts is generally considered to be by the use of a counting chamber such as that described by Helber (1904; see Topley and Wilson's Principles, 1946), but the method described in another connexion by Jones \& Mollison (1948) in which permanent preparations in agar films are made for counting might have some advantages when postponement of the counting is required, and it seemed worth further investigation. A number of tests of the precision of this method were therefore made.

\section{METHOD}

The procedure finally adopted for making the preparations and counting the bacteria was as follows:

(1) One millilitre quantities of $1.9 \%$ agar in normal saline are distributed in plugged test-tubes $11 \mathrm{~mm}$. diam. and held molten in a water-bath at $60-65^{\circ}$. (One batch of New Zealand agar was used throughout the present study.)

(2) The bacterial suspension is mixed well and, with a calibrated Pasteur pipette, $0.2 \mathrm{ml}$. is transferred to $1 \mathrm{ml}$. agar.

(3) By means of a fresh pipette, the agar suspension is mixed well and a drop run into one side of a double Neubauer haemocytometer chamber $(0 \cdot 1 \mathrm{~mm}$. deep) fitted with the standard cover slip; the suspension is mixed again, and a drop run into the other side of the chamber. The glass chamber should be slightly warmed before use so that the agar flows readily.

(4) The agar is allowed to set, which takes about $5 \mathrm{~min}$., and the chamber is then immersed in cold water in a dish. The cover-slip is raised gently by inserting a straight wire into the side trough and the two agar films then 
usually float easily off the glass slide. The films are caught on glass microscope slides and removed from the water. The transfer is facilitated by the use of a dish with a black bottom, strongly illuminated from one side.

(5) The agar films on the slides are trimmed and then allowed to dry in air, and are then mounted under a cover-slip in glycerol jelly.

(6) Counting of the bacteria in the films is carried out with a phase-contrast microscope, using a $\frac{1}{12}$ in. oil-immersion objective and $a \times 6$ eyepiece, with a square mask. Some difficulty may be experienced in counting from the fact that not all the organisms lie in one focal plane; it may be easier therefore to use a $\frac{1}{6}$ in. or a $\frac{2}{3}$ in. objective and a higher power compensating eyepiece.

(7) The number of bacteria per cu.mm. of the agar suspension is calculated from the number per microscope field by using a factor derived from the area of the field in sq.mm. (as determined by a stage micrometer) multiplied by $0 \cdot 1$, the depth of the agar in the haemocytometer chamber.

\section{TESTS OF THE METHOD}

During the preliminary investigations of the method suspensions of streptococci were used, as it was for these organisms that a counting method was to be used, but since the results of many partial tests of the various stages in the technique were amply confirmed in two final comprehensive tests these alone will be described in detail. For one of these a suspension of Streptococcus pyogenes, Type 3 (strain Richards), was used, and for the second a suspension of Bacterium coli (strain D 433). The latter was a culture grown at $37^{\circ}$ for about $12 \mathrm{hr}$. and was almost entirely in the form of single cells; the former had a median chain length of 6.3 cocci. Since the existence of such chains naturally complicates the analysis, the results from the experiment with the Bact. coli suspension will be given first.

Eight agar dilution tubes were melted and cooled to $60^{\circ}$. With a ' 50 -drop' pipette a sample was taken from the suspension and $\mathbf{0 . 2} \mathrm{ml}$. delivered into each of two tubes of agar. With a fresh Pasteur pipette the agar dilution was well mixed and drops were run into the two sides of the counting chamber. Using another pipette this subsampling was repeated. The films were floated off and mounted.

Four traverses, each consisting of the examination of five fields, were made on each film. In each traverse the five fields were spaced more or less equally along either a long- or a cross-axis of the film. The whole process was repeated four times so as to give a total of $\mathbf{3 2}$ films. The examination of the $\mathbf{3 2}$ films was carried out in a random order.

The structure of the experiment was thus as follows:

Samples with 50-drop pipette from culture $(S)=4$.

Dilution tubes for each sample $(D)=2$, i.e. total number of dilution tubes $\left(D^{\prime}\right)=8$.

Subsamples from each dilution tube $(U)=2$, i.e. total subsamples $\left(U^{\prime}\right)=16$.

Films from each subsample $(F)=2$, i.e. total films $\left(F^{\prime}\right)=32$.

Traverses of each film $(T)=4$, i.e. total traverses $\left(T^{\prime}\right)=128$.

Fields examined in each count $(L)=5$, i.e. total fields $\left(L^{\prime}\right)=640$. 
The frequency distribution of the counts of bacteria per field was found to be indistinguishable from a normal distribution (Fig. 1, curve $\boldsymbol{A}$ ). On general principles one would expect a Poisson form of frequency distribution in this case, but with a mean number of cells per field of $26 \cdot 69$ the two distributions are very similar in shape, though the true Poisson distribution has a smaller standard deviation (Fig. 1, curve $B$ ).

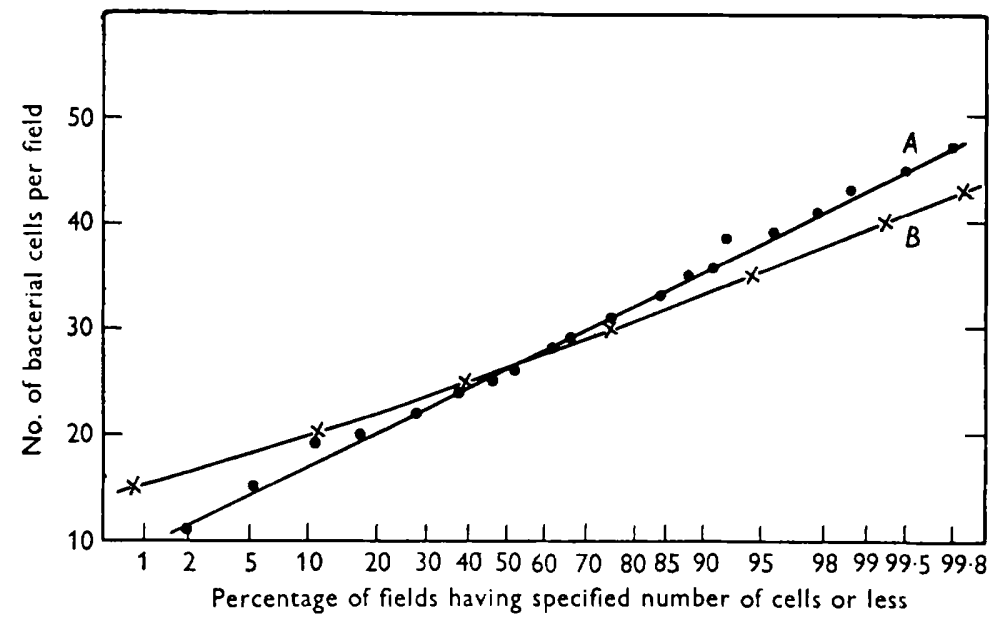

Fig. 1. Frequency distribution of numbers of Bact. coli per microscope field $(A)$, compared with that to be expected from a population having a Poisson distribution with approximately the same mean value $(B)$. Curves drawn on a probability scale for the abscissa, such that a normal distribution is represented by a straight line.

Table 1. Analysis of variance of counts of Bact. coli

\begin{tabular}{|c|c|c|c|c|c|c|c|c|}
\hline $\begin{array}{c}\text { Source } \\
\text { of variance }\end{array}$ & $\begin{array}{l}\text { Sums of } \\
\text { squares }\end{array}$ & $\begin{array}{l}\text { Degrees } \\
\text { of } \\
\text { freedom }\end{array}$ & $\begin{array}{c}\text { Mean } \\
\text { squares }\end{array}$ & $F$ & $\boldsymbol{P}$ & $\begin{array}{l}\text { Mean } \\
\text { squares }\end{array}$ & $F$ & $\boldsymbol{P}$ \\
\hline $\begin{array}{l}\text { Between samples } \\
\text { from suspension }\end{array}$ & $2,267 \cdot 98$ & 3 & $755 \cdot 99$ & 1.77 & $>0.05$ & & & \\
\hline $\begin{array}{l}\text { Between dilution } \\
\text { tubes within } \\
\text { samples }\end{array}$ & $1,710 \cdot 32$ & 4 & $427 \cdot 56$ & $3 \cdot 21$ & $>0.05$ & $568 \cdot 77$ & $5 \cdot 11$ & $<0.001$ \\
\hline $\begin{array}{l}\text { Between sub- } \\
\text { samples within } \\
\text { dilution tubes }\end{array}$ & $1,064 \cdot 80$ & 8 & $133 \cdot 10$ & $1 \cdot 54$ & $>0.05$ & & & \\
\hline $\begin{array}{l}\text { Between films } \\
\text { within subsamples }\end{array}$ & $1,383 \cdot 05$ & 16 & $86 \cdot 44$ & $<1 \cdot 0$ & $>0.05$ & $111 \cdot 34$ & - & 一 \\
\hline $\begin{array}{l}\text { Between traverses } \\
\text { within films }\end{array}$ & $10,912 \cdot 40$ & 96 & $113 \cdot 67$ & $4 \cdot 15$ & $<0.001$ & & & \\
\hline $\begin{array}{l}\text { Between fields } \\
\text { within counts }\end{array}$ & $14,054 \cdot 20$ & 512 & $27 \cdot 45$ & - & - & - & - & 一 \\
\hline Total & $31,392 \cdot 75$ & 639 & - & - & - & - & - & - \\
\hline
\end{tabular}

Analysis of the variance was carried out without transformation (Table 1). The individual mean squares are tested for significance by comparison with the immediately succeeding mean square. Thus the mean square for traverses, $\mathbf{1 1 3 \cdot 6 7}$, is compared with that for fields, $27 \cdot 45$; this gives a variance ratio of 
$4 \cdot 15$, which is highly significant. The variation between the traverses was, therefore, significantly greater than that attributable to the variation between fields. The mean square for films, $\mathbf{8 6 . 4 4}$, is compared with that for traverses, 113.67, and is clearly not significant. The films did not therefore differ more than was to be expected from the variation between traverses. The same is true of subsamples. The variance ratio for dilution tubes, $\mathbf{3 \cdot 2 1}$, is suspiciously high. A new estimate of the total variation within dilution tubes is made by pooling the sums of squares for subsamples, films and traverses (to give $13,360 \cdot 25)$ and dividing by the pooled degrees of freedom (120). Since the mean square for samples is not significantly greater than that for dilution tubes, the sums of squares for these two items may also be pooled. We then have a new mean square for dilution tubes of 568.77 and for the remainder of $111 \cdot 34$, on 7 and 120 degrees of freedom respectively; the variance ratio of $5 \cdot 11$ is highly significant. There appeared, therefore, to be real differences between dilution tubes.

The components of variance may be estimated as follows:

$$
\begin{aligned}
\sigma_{L}^{2} & =27 \cdot 45 ; \\
5 \sigma_{T}^{2}+\sigma_{L}^{2} & =111 \cdot 34, \text { therefore } \sigma_{T}^{2}=16 \cdot 78 ; \\
80 \sigma_{D}^{2}+5 \sigma_{T}^{2}+\sigma_{L}^{2} & =568 \cdot 77, \quad \text { therefore } \sigma_{D}^{2}=5 \cdot 72 .
\end{aligned}
$$

Here $\sigma_{T}^{2}$, for example, is the variance between the true mean counts from traverses on a single film. From these figures an estimate can be made of the fiducial limits for mean counts made with varying numbers of dilution tubes, traverses and fields. Thus, the estimated variance $(V)$ of a mean count is given by

$$
V=\frac{5 \cdot 72}{D^{\prime}}+\frac{16 \cdot 78}{T^{\prime}}+\frac{27 \cdot 45}{L^{\prime}}
$$

where $D^{\prime}, T^{\prime}$ and $L^{\prime}$ are the total number of dilutions, traverses and fields. From this it can be seen that, for any given number of fields counted, and any given number of fields per traverse, the variance is lowest when the number of dilutions made is maximum, and one traverse is made per dilution. A number of representative values are given in Table 2, and it can be seen that, with 40 or 60 fields counted, it is possible to obtain $5 \%$ fiducial limits within $12-15 \%$ of the mean without undue labour.

The experiment with Strep. pyogenes was carried out in an identical fashion, but the frequency distribution of the number of cocci per field was not normal (Fig. 2, curve $A$ ), owing to the fact that the cocci were distributed in chains or clumps comprising from 2 to 20 or more cocci, and no fewer than 89 of the 640 fields examined contained no cocei. Analysis of the untransformed counts gave a suspiciously low value for the between-films mean square. Transformation of the count to $\log _{10}($ count +1$)$ did not produce any very obvious improvement in the shape of the frequency distribution curve (Fig. 2, curve $B$ ), but analysis gave a much more consistent set of mean squares (Table 3 ). The results, as set out in Table 3, conformed well with those obtained in the experiment with Bact. coli but the variance ratio due to differences between traverses was not significant, and the variance due to differences between fields 
was proportionately much larger, presumably as a result of the form of the frequency distribution. In consequence the accuracy of the counts, for a given number of fields examined, is less than with Bact. coli (Table 4).

Table 2. Errors of estimation of mean counts of Bact. coli with different numbers of dilution tubes, etc.

\begin{tabular}{|c|c|c|c|c|c|}
\hline \multicolumn{6}{|c|}{ No. of counts (see text) } \\
\hline$L$ & $D$ & $T$ & $L^{\prime}$ & $D^{\prime}$ & $T$ \\
\hline \multirow[t]{3}{*}{5} & 1 & 4 & 20 & 1 & \\
\hline & 2 & $\mathbf{2}$ & 20 & 2 & \\
\hline & 4 & 1 & 20 & 4 & \\
\hline \multirow[t]{4}{*}{5} & 1 & 8 & 40 & $\mathbf{I}$ & \\
\hline & 2 & 4 & 40 & 2 & \\
\hline & 4 & 2 & 40 & 4 & \\
\hline & 8 & 1 & 40 & 8 & \\
\hline \multirow[t]{6}{*}{5} & 1 & 12 & 60 & 1 & 12 \\
\hline & 2 & 6 & 60 & 2 & 12 \\
\hline & 3 & 4 & 60 & 3 & 12 \\
\hline & 4 & $\mathbf{3}$ & 60 & 4 & 12 \\
\hline & $\mathbf{6}$ & 2 & 60 & 6 & 12 \\
\hline & 12 & 1 & 60 & 12 & 12 \\
\hline
\end{tabular}

\begin{tabular}{c}
$2 \times($ standard error) $\times 100$ \\
\hline mean count \\
(approximate $5 \%$ \\
fiducial limits as \\
percentage of mean) \\
$25 \cdot 2$ \\
21.7 \\
19.9 \\
21.9 \\
17.8 \\
15.4 \\
14.0 \\
20.6 \\
16.3 \\
14.5 \\
13.6 \\
12.6 \\
11.5
\end{tabular}

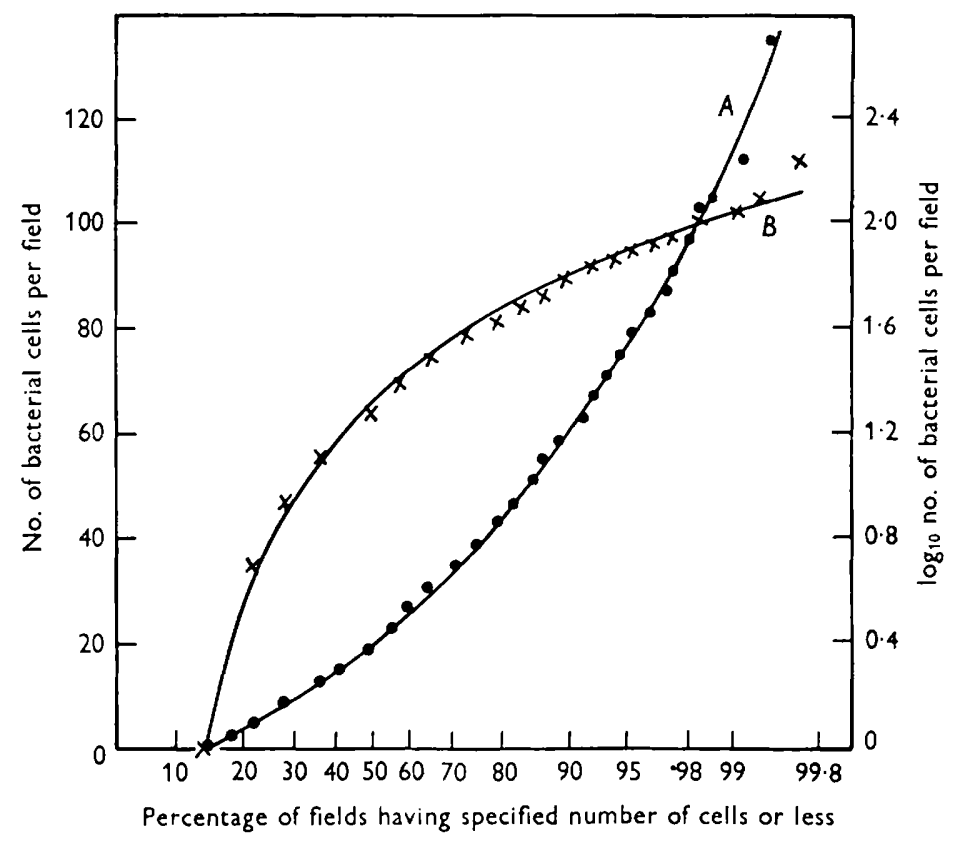

Fig. 2. Frequency distribution of numbers of Strep. pyogenes cells/microscope field, plotted on a probability scale. $A$, arithmetic scale for number of cells (ordinate); $B$, logarithmic scale. 
However, as a further test of the validity of the analysis, the following test was made. For each film, comprising 20 fields, the number of fields with zero count was expressed as a proportion of the total 20, and this proportion transformed to angles by the method of Bliss (see Snedecor, 1946). The analysis of variance due to differences between samples, dilution tubes, subsamples

Table 3. Analysis of variance of counts of Strep. pyogenes, transformed to logarithms

\begin{tabular}{|c|c|c|c|c|c|c|c|c|}
\hline $\begin{array}{c}\text { Source } \\
\text { of variance }\end{array}$ & $\begin{array}{l}\text { Sums } \\
\text { of } \\
\text { squares }\end{array}$ & $\begin{array}{l}\text { Degrees } \\
\text { of } \\
\text { sfreedom }\end{array}$ & $\begin{array}{l}\text { Mean } \\
\text { squares }\end{array}$ & $\boldsymbol{F}$ & $P$ & $\begin{array}{l}\text { Mean } \\
\text { squares }\end{array}$ & $F$ & $\boldsymbol{P}$ \\
\hline $\begin{array}{l}\text { Between samples from } \\
\text { suspension }\end{array}$ & $1 \cdot 357$ & 3 & 0.452 & $0 \cdot 269$ & $>0.2$ & & & \\
\hline $\begin{array}{l}\text { Between dilution tubes } \\
\text { within samples }\end{array}$ & $6 \cdot 722$ & 4 & $1 \cdot 681$ & $8 \cdot 280$ & $0.01-0.001$ & 1.154 & 3.56 & $<0.01$ \\
\hline $\begin{array}{l}\text { Between subsamples } \\
\text { within dilution tubes }\end{array}$ & $1 \cdot 620$ & 8 & 0.203 & $0 \cdot 700$ & $>0.2$ & & & \\
\hline $\begin{array}{l}\text { Between films within } \\
\text { subsamples }\end{array}$ & $4 \cdot 640$ & 16 & 0.290 & 0.779 & $>0.2$ & 0.394 & 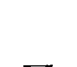 & \\
\hline $\begin{array}{l}\text { Between traverses } \\
\text { within films }\end{array}$ & $35 \cdot 701$ & 96 & 0.372 & $1 \cdot 171$ & $0.2-0.05$ & 0.024 & - & - \\
\hline $\begin{array}{l}\text { Between fields within } \\
\text { traverses }\end{array}$ & $162 \cdot 684$ & 512 & $0 \cdot \mathbf{3 1 8}$ & - & - & & & \\
\hline Total & $212 \cdot 724$ & 639 & - & - & - & - & - & - \\
\hline
\end{tabular}

Table 4. Errors of estimation of mean counts of Strep. pyogenes with different number of dilution tubes

\begin{tabular}{rcccc}
\multirow{2}{*}{$D^{\prime}$} & $\begin{array}{c}2 \times \text { standard } \\
\text { error }\end{array}$ & \multicolumn{2}{c}{$\begin{array}{c}5 \% \text { fiducial limits } \\
\text { as percentage of mean* }\end{array}$} \\
\cline { 3 - 5 } 5 & $L^{\prime}$ & (in logarithms) & Upper & Lower \\
& 10 & $0 \cdot 372$ & 235 & 42 \\
& 20 & $0 \cdot 270$ & 186 & 54 \\
& 40 & $0 \cdot 202$ & 159 & 63 \\
& 60 & $0 \cdot 174$ & 149 & 67 \\
& 10 & $0 \cdot 364$ & 231 & 43 \\
& 20 & $0 \cdot 262$ & 183 & 55 \\
& 40 & $0 \cdot 190$ & 155 & 65 \\
60 & $0 \cdot 160$ & 145 & 69
\end{tabular}

* Upper limit $=100 \times$ [antilog $(2 \times$ standard error $)]$; lower limit $=100 \times$ [antilog $(-2 \times$ standard error)].

and films was then carried out on the transformed variate (Table 5). The between films mean square was compared with the theoretical variance given by $820 \cdot 7 / 20$ (Armitage, personal communication), and found not to be significant. None of the individual variance ratios was significant, but the between dilution tubes mean square was suspiciously large and was further tested after pooling as shown in the table. This gave a significant value for the variance ratio due to differences between dilution tubes, which served as confirmation of the results of the analysis on the logarithms of the counts. 
In both experiments there was a significant variance ratio due to differences between dilution tubes. Molten agar is difficult to measure accurately, and it was thought that an increase in the volume of the dilution tubes might lead to improvement. An experiment was accordingly carried out in which a single suspension of Bact. coli diluted with a single pipette in six $5 \mathrm{ml}$. lots of agar,

Table 5. Analysis of variance of counts of Strep. pyogenes transformed to angles

\begin{tabular}{|c|c|c|c|c|c|c|c|}
\hline $\begin{array}{c}\text { Source } \\
\text { of variance }\end{array}$ & $\begin{array}{l}\text { Sums } \\
\text { of } \\
\text { squares }\end{array}$ & $\begin{array}{l}\text { Degrees } \\
\text { of } \\
\text { freedom }\end{array}$ & $\begin{array}{l}\text { Mean } \\
\text { squares }\end{array}$ & $F$ & $\begin{array}{c}\text { Mean } \\
\text { squares }\end{array}$ & $\boldsymbol{F}$ & $\boldsymbol{P}$ \\
\hline $\begin{array}{l}\text { Between samples from } \\
\text { suspension }\end{array}$ & $628 \cdot 699$ & 3 & $209 \cdot 563$ & $1 \cdot 141)$ & & & \\
\hline $\begin{array}{l}\text { Between dilution tubes } \\
\text { within samples }\end{array}$ & $734 \cdot 827$ & 4 & $183 \cdot 705$ & $3 \cdot 825$ & $194 \cdot 789$ & $4 \cdot 498$ & $0.01-0.001$ \\
\hline $\begin{array}{l}\text { Between subsamples within } \\
\text { dilution tubes }\end{array}$ & $384 \cdot 169$ & 8 & $48 \cdot 021$ & $1 \cdot 173$ & & & \\
\hline $\begin{array}{l}\text { Between films within sub- } \\
\text { samples }\end{array}$ & $655 \cdot 252$ & 16 & $40 \cdot 953$ & $<1$ & $43 \cdot 309$ & - & - \\
\hline Total & $2402 \cdot 947$ & 31 & 一 & - & - & - & - \\
\hline Theoretical variance & - & - & $41 \cdot 035$ & - & - & - & - \\
\hline
\end{tabular}

Table 6. Comparison of 1 and $5 \mathrm{ml}$. dilution tubes

\begin{tabular}{|c|c|c|c|c|c|c|c|}
\hline $\begin{array}{c}\text { Source } \\
\text { of variance }\end{array}$ & $\begin{array}{c}\text { Sums } \\
\text { of } \\
\text { squares }\end{array}$ & $\begin{array}{c}\text { Degrees } \\
\text { of } \\
\text { freedom }\end{array}$ & $\begin{array}{c}\text { Mean } \\
\text { squares }\end{array}$ & $\boldsymbol{F}$ & $\begin{array}{c}\text { Mean } \\
\text { squares }\end{array}$ & $\begin{array}{l}\text { Degrees } \\
\text { of } \\
\text { freedom }\end{array}$ & $F$ \\
\hline \multicolumn{8}{|c|}{$5 \mathrm{ml}$. dilution tubes } \\
\hline Between dilution tubes & $455 \cdot 8$ & $\mathbf{5}$ & $91 \cdot 16$ & $2 \cdot 53$ & $91 \cdot 16$ & $\mathbf{5}$ & $2 \cdot 02$ \\
\hline $\begin{array}{l}\text { Between films within } \\
\text { dilutions }\end{array}$ & $216 \cdot 5$ & 6 & $36 \cdot 08$ & & & & \\
\hline $\begin{array}{l}\text { Between traverses within } \\
\text { films }\end{array}$ & $310 \cdot 8$ & 12 & $25 \cdot 90$ & & $45 \cdot 03$ & 114 & - \\
\hline $\begin{array}{l}\text { Between fields within } \\
\text { traverses }\end{array}$ & $4606 \cdot 6$ & 96 & $47 \cdot 99$ & & & & \\
\hline Total & $5589 \cdot 7$ & 119 & - & & - & - & - \\
\hline \multicolumn{8}{|c|}{$1 \mathrm{ml}$. dilution tubes } \\
\hline Between dilution tubes & $728 \cdot 8$ & $\mathbf{5}$ & $145 \cdot 76$ & $2 \cdot 13$ & $145 \cdot 76$ & $\mathbf{5}$ & $2 \cdot 78$ \\
\hline $\begin{array}{l}\text { Between films within } \\
\text { dilutions }\end{array}$ & $410 \cdot 3$ & 6 & $68 \cdot 38$ & & & & \\
\hline $\begin{array}{l}\text { Between traverses within } \\
\text { films }\end{array}$ & $292 \cdot 2$ & 12 & $24 \cdot 35$ & & $52 \cdot 49$ & 114 & - \\
\hline $\begin{array}{l}\text { Between fields within } \\
\text { traverses }\end{array}$ & $5281 \cdot 0$ & 96 & $55 \cdot 01$ & & & & \\
\hline Total & $6712 \cdot 3$ & 119 & 一 & & - & - & - \\
\hline
\end{tabular}

and also in six $1 \mathrm{ml}$. lots, the order of making the dilutions being random. Two films were made from each dilution and two 5-field traverses carried out on each film. Analysis was carried out as before (Table 6). In this experiment the mean count from the $1 \mathrm{ml}$. dilution tubes was slightly higher than that from the $5 \mathrm{ml}$. tubes, and, although none of the variance ratios was significant there was some indication that the larger dilution volume was associated with a slightly lower variance. 


\section{DISCUSSION}

It is apparent that the two-stage method of carrying out counts of the total number of bacteria in a suspension, by the use of cast agar films, can give a degree of precision of the same order as that given by the direct counting of the bacteria in a Helber chamber, although no thorough analyses of the latter method appear to have been published.

The advantages of the two-stage method of counting are the fact that haemocytometer chambers, which are readily available, can be used, and that the time-consuming process of counting the cells can be postponed to the most convenient occasion if, for some reason, it is thought undesirable to hold the suspensions meanwhile. No change has been observed in mounted or unmounted films kept for several days on the bench. The disadvantage of the method is that the total time taken over the procedure is greater than in a direct counting method, and that practice is required before the several stages can be carried out easily.

It is clear from the analyses that the greater part of the variation between counts is accounted for by the variation between successive fields counted. There is of course a limit, set by the nature of a random distribution of cells across the film, below which this variation cannot be reduced. The fact that, in the experiment with Bact. coli, $\sigma_{L}^{2}$ had the value of $27 \cdot 45$ compared with that of $26 \cdot 69$, which would be the estimate of the variance of a Poisson distribution with the same mean, suggests that this limit is approached. There is, nevertheless, a moderate additional variation produced by differences between traverses, each of five fields, on the film. It has been observed that, in some films, the count is higher at the edge than in the centre. This may well account for some of the between-traverses variation, and it was to reduce the risk of errors from this source that the practice of making the traverses along one axis of the film was adopted. The only other significant source of variation was that due to different dilution tubes and the indications are that this was truly a difference between the tubes and not between the pipettes used for measuring the primary samples, although it is difficult to be certain since there are only 3 degrees of freedom available for measuring the latter variation. It is probable that the effect of the dilution tubes could be reduced by using volumes larger than $1.0 \mathrm{ml}$, although with the larger volume it would be more difficult to ensure mixing.

The number of dilution tubes, films and traverses that would be needed in practice must of course depend on the accuracy required, and also on the density of the cells in the preparation. It is suggested that, with a suspension consisting largely of single cells, and of such density as to give a count per field of the same order of magnitude as in the present work, a reasonable compromise might be to use four dilution tubes, make one film from each tube and perform two traverses, each of five fields, on each film. This amounts to counting 40 fields or, with a density of 25 cells per field, 1000 cells. In the ordinary way it will probably be sufficient to estimate the standard error of an individual count from the variance of the mean counts from the four dilution tubes. 
I am very grateful to Dr P. Armitage, of the Medical Research Council's Statistical Research Unit, for guidance on the methods of statistical analysis and for many helpful comments.

\section{REFERENCES}

Helber, E. (1904). Ủber die Zählung der Blutplättchen im Blute des Menschen und ihr Verhalten bei pathologischen Zuständen. Dtsch. Arch. klin. Med. 81, 317.

Jones, P. C. T. \& Mollison, J. E. (1948). A technique for the quantitative estimation of soil micro-organisms. J. gen. Microbiol. 2, 54.

Snedecor, G. W. (1946). Statistical Methods, 4th ed. Ames, Iowa: Iowa State College Press.

Topley and Wilson's Principles of Bacteriology and Immunity (1946), 3rd ed. Revised by Wilson, G. S. \& Mrees, A. A. London: Edward Arnold and Co.

(Received 6 February 1952) 